\title{
Ontario Report: Process or Content?
}

\author{
Murray G. Ross *
}

The Learning Society. Report of the Commission on Post-Secondary Education in Ontario. Toronto: the Ministry of Government Services, 1972.

The final report of the Commission on Post-Secondary Education in Ontario is such a vast improvement on its Draft Report that one is tempted to greet this new document with unqualified enthusiasm.

The Draft Report published in January 1972 was a near disaster. Ill-conceived and badly written, it shocked the academic world - less by the ideas it proposed than by the level and quality of intellectual activity it represented. The final report, which is entitled The Learning Society, has been tidied up considerably : it is well-organized, clearly focused, and the writing has improved remarkably.

But a comparison with the Draft Report is not an adequate basis upon which to judge the result of the Commission's work. One must see this latter in terms of the time, money and resources available. This is a Commission that has been in existence for four years, it had ample funds (spending $\$ 304,000$ on its meetings, $\$ 671,000$ for research, $\$ 273,000$ for public hearings), members of the Commission visited 11 foreign countries including Japan, Norway, Denmark and West Germany, and it was in receipt of 742 briefs from individuals, groups, and institutions in the Province. Given these resources in time, money and ideas one has a right to expect a thorough examination of the post-secondary system of education in Ontario; a well-documented and reason presentation of problems, issues and solutions; and a series of recommendations that give direction not only to the post-secondary educational system as a whole but for the various parts of that system as well.

If these are the criteria for judging The Leaming Society the reports does not fare well. There is a shocking lack of detail about the present institutions of higher learning, an absence of references to their specific strengths and weaknesses, and an abundance of sweeping generalizations without adequate documentation.

* Murray G. Ross, Professor, Social Sciences, York University. 
The only reference to specific colleges or universities is in the section on "Bilingual Balance" where short statements appear on the bilingual programs at the University of Ottawa, Laurentian University, and Glendon College. The report stresses the need for diversity, for the Commission is deeply concerned about "the process of homogenization" in post-secondary education, yet no mention is made of the problems of, say, Trent University which seeks to be somewhat distinctive, nor of the Ontario Institute for Studies in Education which is surely unique among institutions of higher education in the world. The report gives considerable attention to the need for adult and continuing education, yet no mention is made of the value or otherwise of Atkinson College which is the only college in the province (and one of the few in the world) which has a building of its own and a faculty specifically appointed to serve part-time students. In the search for models for the future the Commission depends on generalizations without any examination of the possibility that we may already have in Ontario some institutions that hold great promise for the future.

Nor does the Commission deal with the fundamental problems which confront colleges and universities at the present time. Most authorities (Ashby, Trow, Ben-David, Nisbit, et al.) agree that the central problem of the university today is the lack of consensus about goals. The traditional goals of the university (the creation of new knowledge, the transmission of "the high culture," the sifting required to maintain the certified elite group) are now in deep conflict with certain popular functions of the university (to provide universal higher education and to make available information and applied knowledge to organizations of all types). The great danger in North America today - acknowledged by all serious students of higher education - is that these popular functions will swamp the university and gradually push into oblivion the great traditional functions of that institution.

The Commission never comes to grips with this issue, although Professor J.M.S. Careless in a "Reservation" points out the difficulty of reconciling two of the major thrusts of the report: universal accessibility and quality. These are, indeed, seemingly incompatible goals and they are not made less so by the generalized and ambiguous statements that prevail in the Commission's Report. For example, the following statement appears on page 44 : "To make lifetime learning opportunities more widely available post-secondary institutions should give persons who have been out of full time education for two or more years, and who have reached a minimum age of 18 , conditional admission to appropriate programs without asking them to meet formal requirements." On the next page the Report says: "Although colleges and universities are likely to remain leading centres of continuing education in Ontario, we do not think they can accomplish this task alone without seriously eroding their integrity through overloading." Thus are universal accessibility and quality reconciled! The problem is, of course, an extremely complex and difficult one but it is not to be resolved by jumping from one side to the other. We have to say whether or not we believe a university should, as one of its main functions, cater to an "intellectual elite", i.e. superior scholars (both students 
and faculty members) whose disposition is to run far ahead and far afield in their pursuit of knowledge and who are ill-equipped to participate in "popular, accessible, flexible, and diverse education." Such scholars know only serious scholarship and require protection from the requirement of being popular or relevant. I am not certain the Commission wants such elitism in our universities. If it does it does not say so. The emphasis seems to be clearly on the popular functions.

At one point, after recommending some changes in the posture of colleges and universities in remote areas, the Commission states (p. 49), "We became acutely aware of this trend [toward homogenization] in our survey of curricular patterns in Ontario." This is all that is said about this survey, or about curriculum, at this or at any other point, in the report. One would like to know not only something about the survey - its extent and results - but also what views, if any, the Commission has about the curriculum in the colleges and universities in Ontario. What do students, the public, the Commission think about the present curriculum in colleges and universities? Is reform required? If so, where and in what respects? Or is it sufficient if all colleges and universities strive for "flexibility and diversity?"

Perhaps it is unfair to expect the Commission to deal with existing institutions and with current issues. It has given prior attention, I think, to one item in its terms of reference: "to provide full opportunity for all interested individuals and organizations to express opinions and offer discussion on both broad and specific issues..." This it did most effectively. Perhaps, as a result, its focus is on change and the future. There is in Part One of the Report, "Prologue to Change," a cursory bow to the past, which (except for a few brief references to the University of Toronto Acts of 1887 and 1906) seems to begin in 1945. The Commission, perhaps because of the way it worked, came to see its task as drafting, in broad outline, the changes which should come about in the immediate future. And perhaps its emphasis is correct: what we may require is preparation to meet the popular demands of the day. One may disagree with some of its proposals or may think it does little justice to that which Ontario now possesses, but if one accepts the Commission's prime task to be that of suggesting some ideas which might broaden opportunities for education at the post-secondary level in the future, then one must acknowledge that the Commission has moved some distance towards its goal.

In spite of the multiplicity of subjects covered in the Report there are, I think, five broad themes : (1) a broad system of post-secondary education open to all, (2) a system which eradicates some of the inequities that now exist in the post-secondary system in respect of women, native people, Franco-Ontarians, etc., (3) a system which brings education and work closer together, (4) a new structure by which a "buffer" is created between government and institutions of post-secondary education, and (5) a method of financing which, while maintaining the formula, simplifies this system of grants and separates instructional and research costs so that the latter will be provided to able researchers irrespective of their responsibility for graduate students. This is a very 
considerable agenda in the working through of which the Commission offers some novel and useful ideas.

The Commission is anxious that opportunities for post-secondary education be available to all. It seems almost to posit a situation in which everyone over the age of 18 is involved in some kind of educational experience. To this end it suggests not only making existing colleges and universities more accessible (it never mentions other institutions such as training schools for nurses, chiropractors, denturists, etc.) but creating new opportunities by (a) "viable, paid alternatives to remaining in school" (p. 51), by increased support to Canadian University Service Overseas, Frontier College, certain Opportunities for Youth projects and in-service training programs in a wide range of industrial, non-industrial, and government operations, and (b) an Open Academy of Ontario which, using existing facilities and resources, would "develop new programs suited to the needs of students not presently served in existing institutions" (p. 55), and which, in cooperation with the Ontario Communications Authority would "... develop appropriate post-secondary educational materials and programs" (p. 55) for radio and television. The Commission is convinced that there is a "yearning for learning" on the part of the masses of people (although there is no evidence presented to support this assumption), but that, in any case, massive programs are necessary. "What is required, in fact, is still more widely disseminated learning, to enable the ever more involved and delicately balanced processes of civilization to endure and grow. In short, we must inevitably seek to become a full-scale learning society, for all ages, at all levels - and particularly at the post-secondary level"' (p. 169).

In respect of the second theme, the Commission is indignant at discrimination, in post-secondary education, against women, native people, and Franco-Ontarians. There are, therefore, the now popular recommendations about giving the sexes equal opportunities and rewards. (Fortunately, the proposal in the earlier Draft Report requiring post-secondary institutions to meet specific quotas by specified dates has been dropped.) In respect of native people, where opportunities for education of any substantial kind are obviously inadequate, there is a proposal for "an Advisory Committee on PostSecondary Education for the Native People of Ontario" which would be concerned with expanding library services, college and university courses, make-up programs, etc. for native people, particularly in remote northern regions. The Commission goes a long way in providing for Franco-Ontarians. (In 1971 there were 482,000 people in Ontario whose first language was French, although there were in that year only 25,212 students enrolled in French-language high schools, p. 79-82.) It is recommended not only that the existing bilingual universities (Ottawa, Laurentian) and Glendon College should expand their offerings in French but "immediate and special attention should be paid to expanding and/or establishing French-language programs in the health sciences, library science, and education, as well as programs in technical, commercial, and continuing education" and "examinations for admission to any grade or profession in Ontario should be available in French upon request" (p. 92). These are all popular causes to which most 
academics would say "amen," but there is no estimate as to costs nor any explanation of how the Commission, in its four years of work, discovered these to be "high priority" items for the agenda of post-secondary education in Ontario.

The third area given prominence relates to "careers and education" and is concerned with relating educational offerings to job opportunities. To this end the Commission recommends an Ontario Human Development Commission (as part of a Canadianwide plan) which, among other duties, would "offer to the public information on educational training and employment opportunities and manpower needs" (p. 99). This information should be stored in a computer, kept up-to-date, and made available through a wide variety of counselling centres - some even in shopping plazas.

A major section of the Report - and of great importance to the future of colleges and universities in Ontario - relates to structure. The Commission is concerned with finding a way of reconciling the need for educational institutions to have a high degree of freedom and autonomy with the need of government to control these institutions to which it contributes such vasts sums annually. A "buffer" between government and post-secondary institutions in the form of four appointed Councils is proposed. These are: (1) the Council for College Affairs, (2) the Council for University Affairs, (3) the Council for the Open Sector, and (4) the Council for the Creative and Performing Arts. These four councils, it is suggested, will operate in relation to a new ministry - the Ministry of Post-Secondary Education - but each will have clearly delegated authority to carry out the responsibilities assigned to it. The Commission concedes to the government the authority to decide from amongst competing claims for its resources, i.e., it will decide how much money should be allocated each year to post-ser,ondary education. But decisions in respect of allocation of this sum among various institutions and the purposes for which these monies are to be used are to be kept away from government and delegated to the "buffer" councils (p. 42). Specifically, the Councils would : (1) advise the government as to the global funds needed..." (2) "allocate and distribute funds..." and (3) "plan and co-ordinate the overall development of their respective sectors" (p. 113). ${ }^{1}$ The Commission, in spite of a few kindly words about the Council of Ontario Universities, does not think that "voluntary co-operation", upon which C.O.U. is based, will work and thinks that it (C.O.U.), represents a very expensive and ineffective instrument for the tasks required. There is, however, a role for C.O.U. and other such voluntary associations: "The lobbying activities of groups of institutions, students, faculty, and staff are an indispensable part of our modern democratic process in post-secondary education" (p. 118).

Since the four Councils will have very substantial powers their composition is of considerable import. For the Council for University Affairs a membership of 14 (in addition to a full-time chairman) is recommended : two members each appointed from nominations from the Council of Ontario Universities, the Ontario Confederation of University Faculty Associations, the provincial student association; one member from nominations of representative associations of labor, management, the professions, etc. ; 
and one from the Ontario Teachers Federation (p. 124). No university president or chief executive officer is to be appointed to Council.

An organization cannot in itself solve problems. The success of the structure proposed will depend upon the quality of people appointed to the four Councils, the manner in which they use their authority, the degree to which they consult before making decisions, the co-operation of government and the institutions involved. Nonetheless this proposal goes a considerable distance towards removing some present difficulties, at least for the universities. It is protection against many kinds of arbitrary government action ; it does promise autonomy in a number of areas (e.g., no line-budgeting); and it does place the authority of the Council largely in the hands of university people. It appears to be a sensible solution and a desirable step beyond the present structure, in which the "buffer" - the Committee on University Affairs - is advisory only, leaving the universities subject to direct government intervention.

The fifth main area relates to a new method of providing grants to institutions in each of the four recommended sectors. There are proposals for increased grants for institutions in the open sector (libraries, museums, art galleries, etc.) and for organizations in the creative and performing arts, but those of greatest interest to academic relate to the proposed new grant formula for universities and a new plan for student financial aid.

The Commission recognizes "the steering effect" of the present formula system and proposes to change it : (1) by separating "a subsidy for educational or instructional functions (including research and scholarship vitally associated with instruction)...", and "payments for research and other activities where applicable, on a long-term basis. (no fewer than three but no more than five years) and following quality assessment within each field or discipline" (p. 142), and (2) by simplifying the formula system of grants by providing income on the basis of "official enrolment estimates, calculated from the institutions' previous years weighted enrolment adjusted by the sum of its projected weighted enrolment changes" (p. 44). This latter will undoubtedly make life much easier for those responsible for budgeting in colleges and universities but the division of the budget into "instruction" and "research" is fraught with difficulties.

The Commission, as at so many points, seems on both sides of this problem. At one point it says, "The task of separating the functions of instruction and research and funding them separately is not as difficult as is sometimes thought" (p. 142). A few paragraphs later it says "where the line is drawn is a matter of judgment...", and then a few lines further "... people of good will are likely to disagree on where the separation should be made". But the problem is neatly resolved by saying, "We suggest that the determining factor should be whether or not the research effort and cost in question can be regarded as essential to teaching" (p. 142). Really! Anyone who knows academic life knows how extremely difficult (if not impossible) it is to make such a distinction. ${ }^{2}$ This recommendation I assume to be, at least in part, an effort to provide research funds 
for those not teaching graduate students (and thus to reduce the ambition of everyone in the university to have graduate students and large grants) and, for this reason, is admirable. But we have a right to expect from a Commission working four years on this problem, some assurance that it has worked through the budget of several universities, with this division in mind, and as a result of careful calculations, is able to tell us if the plan is feasible or not. One suspects that chaos might result from the implementation of this recommendation. We should know if this recommendation is something more than a bright idea that inspired someone on the Commission. It is far too important a proposal to be placed formally before the government before careful testing and consultation.

The Commission is anxious to remove all financial barriers to post-secondary education and proposes a three-level program of (1) scholarships and graduate fellowships for outstanding students, (2) grants "scaled according to the recipient's parents' income group and size of family..." (P. 147) to cover fees and maintenance costs for the first five years of post-secondary education or the equivalent in part-time studies, and (3) loans to supplement grants, or for students not eligible for grants. A sum of $\$ 3$ million annually is suggested for all these purposes. There is no discussion of the problem of operating a means test for several hundred of thousands of students.

In all there are 126 recommendations of the Commission and in a review of limited length one is forced to be selective, as I have been above. There are many other interesting comments and recommendations : on research (it's good), the length of the academic year (it's fine as it is), moonlighting by professors (it's bad), grants for church-related institutions (they should have them if they ignore religion), in loco parentis (forget it), laymen on university boards (good if they work at it), an ombudsman for post-secondary education (should have one to keep up with the Swedes), professions (they're monopolistic and elitist and we must be certain all religions, socioeconomic strata, sexes, and races are properly represented in them), degrees (not very valuable and should be given by all, e.g., the College of Art, the Colleges of Applied Arts and Technology, Open Academy, etc.), graduate studies (concentrate in a few centers), transfers (must have an open and flexible system - except from community colleges to university even though the absence of such transferability "clearly brings hardships to individual students..." (p. 50)), Grade 13 (it's unnecessary), goals for post-secondary education (social responsiveness, quality, diversity, flexibility, openness), and so on.

The rapidity with which such issues are raised and resolved overwhelms one. One is left to speculate whether the Commission spent five minutes or five hours or commissioned a $\$ 100,000$ study on any particular issue. There is no way of knowing. For example, the question of the length of the academic term in universities is discussed in a few lines. This is a subject on which the Commission had a study made by Woods, Gordon, a firm of management consultantș. But all we are told in the Commisșion's 
Report is that the year-round school is not cheaper. There is no discussion of what is pedagogically sound. For example, does the highly congested present term (mid-September to April 1st) provide a better learning experience than an extended term with reading periods? What other alternative is there? What did the Commission discover about this on their jaunts to England, Japan, Switzerland? We are not told. We are simply told that the academic year is fine as it is.

Indirectly, the Commission's Report raises a very large and fundamental question about trends in our universities and in our society. The Commission was devoted to "due process." It was composed of people with varying interests in post-secondary education: a few students (or recent students), a few professors, a university president, a community college principal, etc., with a few representatives of labor, industry, etc. If representation of "the field" and the public was required, it was provided. The Commission issued a Statement of Issues to stimulate public discussion and debate. It held hearings. It then issued a Diaft Report after which it held more hearings. In terms of involving a large number of people from many sectors of the community it was most successful. If the criterion of a good report is whether or not enough of "all the people" had some part in creating and producing it, then the Commission did its job effectively. The popular demand of our day for due process has been served.

But if one is primarily concerned with content, one's judgment of the Report must be more conservative. It is not much to show for four years work and an expenditure of $\$ 1,530,000$. There are some good ideas presented, some obvious needs identified, some useful clues for the future offered. But the Report is not a scholarly search for understanding and direction; it is not a careful sifting of the evidence; it is not a well-documented or tightly argued presentation of problems and solutions.

But this merely highlights the issue we confront - the question is whether we are not now more concerned about process than about content. Many of our universities seem to be caught inextricably in this same trap. We seem to give more attention to establishing procedures for getting answers than to the answers themselves. It is probable that some members of the Commission will say, "because of the process we followed our recommendations are realistic and will be implemented." Perhaps - but are they good recommendations?

\section{References}

1. While it is clear the Commission proposes that the Government establishes the global anount for post-secondary education and that the Councils decide the amount for each institution in its sector, it is not clear who decides the amount each Council or sector receives.

2. I am reminded of a remark made by Lord Radcliffe on his installation as Chancellor of the University of Warwick in 1967 . He was referring to another blurred distinction not unlike the above: "Speaking for myself, I do not believe for one moment in the reality of this distinction, and I do not believe that it will or can be observed in practice. There is no line of maintainable frontier between control of use and control of purpose." 